\title{
Korelasi antara Poligami, Tasawwuf Falsafi, dan Irfani
}

\author{
Awaliyah Musgamy \\ Dosen Fakultas Syariah dan Hukum \\ UIN Alauddin Makassar
}

\begin{abstract}
The key to the permanence of marital ties, both monogamy and polygamy, is of course due to the foundation of love. However, if the nature of this love is based solely on the spouse or mere happiness of the world, it is only natural that a dispute occurs. The concept of philosophical Sufism and the theory of Irfani teach that the basis of marriage should be to anchor that holy love to the Supreme Love, in the fusion of self and ego to mortal towards Him. So even in polygamy, everyone in the family will not do it because they expect other praise. But all choices and blessings are imprinted only on the Divine of God.
\end{abstract}

Keywords: Polygamy, Philosophical Sufism, and Irfani

\section{Latar Belakang}

Sebagai insan yang memiliki fitrawi untuk mencintai lain jenis adalah hal yang wajar. Namun terkadang takdir tidak seperti apa yang diharapkan. Manusia mempunyai impian seperti kebanyakan terjadi di kalangan masyarakat. Penilaian khalayak ramai menjadi pembenaran dan seringkali berbeda dengan apa yang dianjurkan oleh agama.

Salah satu ajaran agama khususnya dalam islam adalah berpoligami. Pada umumnya, poligami adalah ketika seorang pria yang menikahi lebih dari satu wanita dan maksimal hanya empat wanita asal memenuhi semua persyaratan yang telah ditetapkan (khususnya dalam islam), antara lain pihak pria sanggup dan mampu bersikap adil pada semua istri.

Praktik poligami yang tidak berlandaskan pada keadilan akan menimbulkan berbagai bentuk ketidakadilan gender (gender inequality). Ketidakadilan tersebut biasanya berupa pembunuhan psikologi, pemiskinan perempuan, dan marginalisasi perempuan ${ }^{114}$.

Keadilan atau kesanggupan menjadi tolok ukur yang abstrak dan bias untuk ditafsirkan. Masing-masing orang mengukurnya berdasarkan tingkat pendidikan, pengaruh lingkungan, intuisi, epistemology, bahkan tergantung dari wawasan atau pengalaman.

Adapun alasan rasional yang bisa diterima, adalah ketika berpoligami berlandaskan azas kemanusiaan. Idealnya, azas kemanusiaan ini terikat pada kesadaran akan spritualitas. Dalam

\footnotetext{
${ }^{114}$ Rif'atuz Zuhro. Poligami, antara islam, cinta, dan realitas. http://www.nu.or.id/post/read/64601/poligami--antaraislam-cinta-dan-realitas 2015, Diakses pada tanggal 05 Januari 2019
} 


\section{An-Nisa', Volume XI Nomor 1 Januari 2018}

puncak kajian cinta yang mengarah pada spritualitas sejati ada pada diskursus keagamaan dan ketika disandingkan dengan tasawwuf atau konsep irfani.

Awalnya, para tokoh tasawuf bergaul dengan setiap lapisan masyarakat. Prototipe ideal yang bisa menjadi contoh adalah Nabi Muhammad S.A.W., yang merupakan pendiri dan pondasi awal, sufi besar walaupun lebih dikenl dengan gelar kenabiannya. Menurut Abu'l-Majd Majdud Sana'i dalam kitabnya Hadiqat al-Haqiqat wa shari'at at-Tariqat dalam Annemarie Schimmel menjelaskan bahwa, "kini tasawuf adalah nama yang tanpa kenyataan, tetapi dulu ia merupakan kenyataan tanpa nama, kepura-puraannya dikenal luas dan pelaksanaannya tak diketahui. ${ }^{115}$

Tasawwuf memang pada umumnya tak terlihat secara empiris dan gerakannya tak bisa dinilai oleh kasat mata. Terkait hal ini, Annemarie Schimmel dengan tegas menyatakan bahwa sejak semula, para ahli mistik dengan tegas membedakan antara sufi sejati, yakni mutasawwif yang berusaha mencapai tingkat rohani yang lebih tinggi, dan mustawif, yakni orang yang berpura-pura menjadi seorang ahli mistik tetapi yang sebenarnya merupakan pengganggu yang tak berguna, dan bahkan membahayakan. ${ }^{116}$

Konsep poligami yang dilandasi ketauhidan yakni kecitaan pada Ilahi melalui pendekatan tasawwuf falsafi dan irfani, akan menjadikan pelakunya sebagai orang yang bertanggung jawab (khususnya pada suami) dan bagi para isteri, tidak aka nada rasa iri, tindak menguasai pasangan, dan menjadikan harta sebagai tolok ukur kebahagiaan. Sebab seluruh komponen keluarga yang berpoligami menggunakan landasan ini hanya akan menjadikan Tuhan sebagai niat segala ibadah serta siap akan pertanggung jawaban di akhirat kelak sebagai kehidupan abadi nan kekal di sisiNya.

\section{Konsep Poligami}

Sebenarnya, praktik poligami sudah banyak dilakukan kaum-kaum jahiliah bahkan abad yang menjalankan sistem kerajaan tepatnya sebelum hukum Islam datang. Bedanya adalah dahulu tidak ada aturan yang mengikat tentang berapa banyak perempuan yang boleh dinikahi sehingga lelaki bisa nikahi perepuan sebanyak yang diinginkan. Agama Islam datang juga tidak melarang praktik poligami tersebut, tetapi membolehkan dengan dengan beberapa aturan dan konsekuensi. Kebolehan hukum tersebut juga diperjelas pada Q.S An-Nisa': 3 yang artinya,

\footnotetext{
${ }^{115}$ Annemarie Schimmel, Dimensi Mistik Dalam Islam, terj. Supardi Djoko Damono dkk. (Jakarta: Pustaka Firdaus, 2000), h. 24.

${ }^{116}$ Ibid. h. 23
} 
"Dan jika kamu khawatir tidak akan mampu berperilaku adil terhadap (hak-hak) perempuan yatim (bilamana kamu menikahinya) maka nikahilah perempuan (lain) yang kamu senangi; dua, tiga, atau empat. Tetapi jika kamu khawatir tidak akan mampu berlaku adil, maka nikahilah seorang saja. Atau hamba sahaya yang kamu miliki yang demikian itu lebih dekat agar kamu tidak berbuat zalim”.

Berdasarkan ayat tersebut, ada beberapa hal yang bisa digaris bawahi diantaranya:

a. Poligami itu sejatinya bukan murni ajaran Islam, melainkan fakta peradaban yang sudah turun-temurun hingga saat ini dan sering dilakukan oleh banyak orang sebelum ajaran islam membatasi jumlahnya.

b. Tuhan (khususnya dalam ajaran Islam) telah memberikan peringatan pada mayoritas laki-laki agar berlaku adil, sebab adil ialah konsekuensi mutlak untuk pria yang melakoni praktik poligami. Ketika laki-laki berlaku zalim, maka ia tidak hanya menzalimi keluarganya tapi juga terhadap dirinya sendiri (di akhirat kelak diminta juga pertanggungjawabannya).

c. Para mufassir sepakat tentang batasan perempuan yang bisa dinikahi hanya sampai 4 orang berdasarkan dengan dalil syara' yang dianggap benar.

d. Terdapat peringatan di akhir ayat tersebut bahwa potensi monogami itu ada ketika dikhawatirkan tak bisa berbuat adil.

e. Lelaki punya andil dalam memilih perempuan yang ingin ia nikahi. Meski demikian Tuhan pun menegaskan pada ayat lainnya bahwa dari segi perasaan, para lelaki takkan mampu bersikap adil. Sebagaimana tertera dalam QS. An-Nisa ayat: 129, yang artinya:

"Dan kamu sekali-kali tidak akan dapat berlaku adil di antara isteri-isteri(mu), walaupun kamu sangat ingin berbuat demikian, karena itu janganlah kamu terlalu cenderung (kepada yang kamu cintai), sehingga kamu biarkan yang lain terkatung-katung. Dan jika kamu mengadakan perbaikan dan memelihara diri (dari kecurangan), maka sesungguhnya Allah Maha Pengampun lagi Maha Penyayang”.

Poligami dalam prakteknya seringkali ditolak oleh kaum hawa karena merasa tersaingi dan keluarganya diganggu. Terlepas dari faktor tersebut dan ajaran agama apapun, ataupun aturan 


\section{An-Nisa', Volume XI Nomor 1 Januari 2018}

negara serta tradisi yang ada haruslah berdasarkan pertimbangan yang rasional walaupun kenyataannya hal ini masih terbilang jarang untuk dijadikan pertimbangan. Diantaranya adalah:

a. Menikahi janda tua yang memiliki banyak anak dan tidak mampu membiayai keluarganya.

b. Menikahi perempuan yang cacat (buta,tuli,bisu,lumpuh) namun masih sehat secara jasmani maupun rohani.

c. Menikahi janda yang diceraikan oleh suaminya karena dituduh mandul (padahal yang mandul adalah mantan suaminya atau fitnah belaka)

d. Menikahi wanita dengan tujuan menyelamatkan agar wanita itu tidak terjerumus menjadi PSK atau kupu-kupu malam.

e. Menikahi wanita miskin, baik janda maupun tidak janda dengan tujuan membantu perekonomiannya dan berusaha menjadi pembimbing dan pelindungnya.

Sebaliknya, adapula poligami yang tidak dilandasi rasionalitas - berdasarkan syahwat saja ialah poligami yang tidak dilandasi kepentingan kemanusiaan, tetapi berdasarkan kepentingan nafsu biologis semata. Antara lain adalah hanya mau menikahi wanita yang masih muda, wanita yang tidak cacat, wanita yang masih perawan, wanita yang ekonominya sudah mapan. Ciri wanita lainnya adalah yang putih, mulus, cantik, seksi, bahenol, intinya secara inderawi masuk kategori model.

Para ulama berbeda pandangan perihal praktik poligami ini, setidaknya terbagi menjadi dua pendapat. Pertama, kalangan Syafiiyah dan Hanbaliyah yang tampak menutup pintu poligami karena dianggap rawan dengan ketidakadilan sehingga keduanya tidak menganjurkan praktik poligami. Madzhab Syafi'i dengan jelas tidak menganjurkan praktik poligami, bahkan Madzhab ini mempertegas sikapnya bahwa praktik poligami tidak diwajibkan sebagaimana kutipan Syekh M Khatib As-Syarbini dalam Mughnil Muhtaj berikut ini. ${ }^{117}$

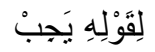

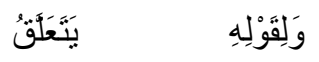

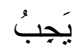

${ }^{117}$ Syekh M Khatib As-Syarbini, Mughnil Muhtaj, Beirut, Darul Fikr, tanpa keterangan tahun, juz 3, hal. 125 
Artinya, "Nikah itu tidak wajib berdasarkan firman Allah (Surat An-Nisa ayat 3) 'Nikahilah perempuan yang baik menurutmu.' Pasalnya, kewajiban tidak berkaitan dengan sebuah pilihan yang baik. Nikah juga tidak wajib berdasarkan, 'Dua, tiga, atau empat perempuan.' Tidak ada kewajiban poligami berdasarkan ijma "ulama”.

Sementara kalangan Hanafiyah menyatakan kemubahan praktik poligami dengan catatan calon pelakunya memastikan keadilan di antara sekian istrinya. ${ }^{118}$

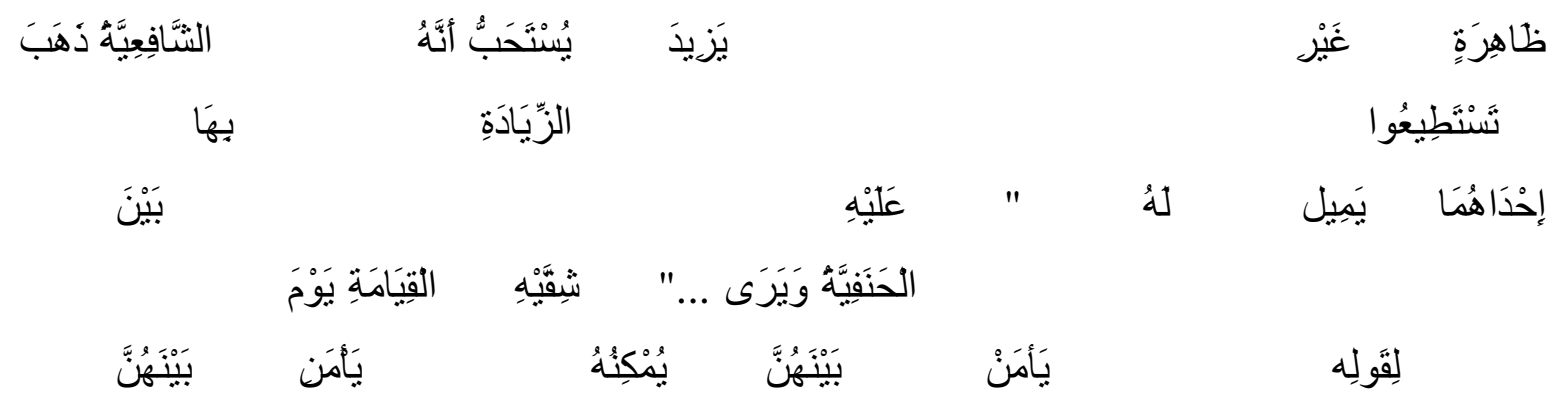

Artinya, "Bagi kalangan Syafi'iyah dan Hanbaliyah, seseorang tidak dianjurkan untuk berpoligami tanpa keperluan yang jelas (terlebih bila telah terjaga [dari zina] dengan seorang istri) karena praktik poligami berpotensi menjatuhkan seseorang pada yang haram (ketidakadilan). Allah berfirman, Kalian takkan mampu berbuat adil di antara para istrimu sekalipun kamu menginginkan sekali.' Rasulullah SAW bersabda, 'Orang yang memiliki dua istri, tetapi cenderung pada salah satunya, maka di hari Kiamat ia berjalan miring karena perutnya berat sebelah.' ... Bagi kalangan Hanafiyah, praktik poligami hingga empat istri diperbolehkan dengan catatan aman dari kezaliman (ketidakadilan) terhadap salah satu dari istrinya. Kalau ia tidak dapat memastikan keadilannya, ia harus membatasi diri pada monogami berdasar firman Allah, 'Jika kalian khawatir ketidakadilan, sebaiknya monogami.

Alasan terkait masalah yang diangkat pada kutipan di atas membahas boleh atau tidaknya praktik poligami yang didasarkan pada bisa atau tidaknya berbuat adil dalam hal jadwal mendatangi istri (nafkah batin), nafkah finansial, atau kasih sayang terhadap anak-anak.

Menurut Syekh Wahbah Az-Zuhayli, bangunan ideal rumah tangga Muslim adalah monogami. Praktik poligami adalah sebuah pengecualian dalam praktik rumah tangga. Praktik ini bisa dilakukan dengan sebab-sebab umum dan sebab khusus. Walhasil, hanya kondisi darurat yang membolehkan seseorang menempuh praktik poligami. ${ }^{119}$

\footnotetext{
${ }^{118}$ Mausu'atul Fiqhiyyah, Wazaratul Awqaf was Syu'unul Islamiyyah, (cetakan pertama, Kuwait, 2002 M/1423 H), juz 41, hal. 220

${ }_{119}$ Syekh Wahbah Az-Zuhayli, Al-Fiqhul Islami wa Adillatuh, (Beirut, Darul Fikr, cetakan kedua, 1985 M/1405 H), juz 7, hal. 169
} 


\section{An-Nisa', Volume XI Nomor 1 Januari 2018}

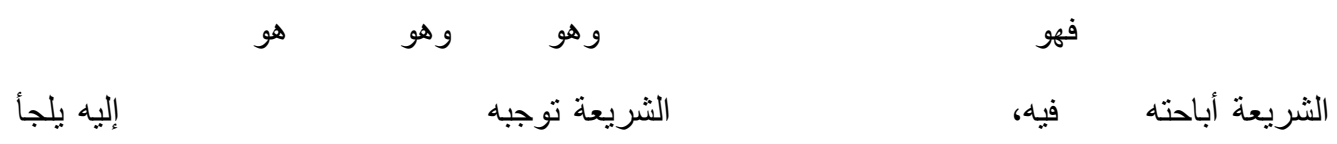

Artinya, "Monogami adalah sistem perkawinan paling utama. Sistem monogami ini lazim dan asal/pokok dalam syara'. Sedangkan poligami adalah sistem yang tidak lazim dan bersifat pengecualian. Sistem poligami menyalahi asal/pokok dalam syara'. Model poligami tidak bisa dijadikan tempat perlindungan (solusi) kecuali keperluan mendesak karenanya syariat Islam tidak mewajibkan bahkan tidak menganjurkan siapapun untuk melakukan praktik poligami. Syariat Islam hanya membolehkan praktik poligami dengan sebab-sebab umum dan sebab khusus."

Dari segi prespektif gender ada beberapa faktor, poligami dipandang dapat menimbulkan perasaan inferior. Pertama, yaitu istri cenderung mengalah, menyalahkan diri sendiri jika diduakan, karena kebanyakan istri merasa suaminya berpoligami sebagai akibat dari ketidakmampuan dirinya dalam melayani dan memenuhi kebutuhan biologis suaminya. Atau juga karena merasa memiliki kekurangan dan harus ditutupi oleh istri lainnya.

Disamping itu ada ketergantungan secara ekonomi pada suami. Maksudnya ketika istri dalam rumah tangga tidak mempunyai penghasilan maka seluruh interaksi ekonomi bergantung pada pemberian/nafkah suami. Di saat kesenjangan antara suami-isteri terjadi maka salah satu pihak yang merasa superior akan berlaku sesuai dengan apa yang diinginkan. Apalagi ketika isteri yang dimadu, atau isteri yang kedua, ketiga dst, maka ketidaksamaan derajat inilah yang akan muncul sebagai awal dari tindak kekerasan dalam rumah tangga. Maka sangat perlu sekali laki-laki dan perempuan mempunyai pemahaman dan visi misi yang sama dalam menjalankan roda pernikahan mereka. Terutama bagi suami yang selalu membimbing seluruh istrinya.

Faktor berikutnya adalah mubah/ dibolehkannya hukum poligami, dalam masyarakat sering disalahgunakan oleh oknum-oknum yang tidak bertanggung jawab, dan jelas mayoritas korbannya adalah perempuan. Misalkan laki-laki yang ingin melakukan poligami tidak mendapatkan izin resmi dari pengadilan agama maka bisa jadi ia melakukan nikah di bawah tangan/ nikah siri, yaitu perkawinan yang tidak dicatatkan pada kantor pencatatan nikah (Kantor Catatan Sipil atau KUA). Perkawinan yang tidak dicatatkan dianggap tidak sah oleh negara, walaupun perkawinan tersebut sah menurut agama. Bila ini terjadi, maka yang dirugikan adalah pihak perempuan karena perkawinan tersebut dianggap tidak pernah terjadi oleh negara. 
Akibatnya, segala konsekwensinya juga terkait perolehan hak dalam hukum nikah secara kenegaraan tidak diperoleh.

Kerugian lain dalam hal poligami adalah dijadikan ketika dijadikan tameng kebolehan hukum agama untuk orang-orang yang tidak bertanggung jawab. Misalkan nikah siri, nikah mut'ah (kawin kontrak), bahkan human trafficking (perdagangan manusia) yang hanya ingin mengambil keuntungan dari perempuan dengan segala resiko yang dibebankan oleh perempuan itu sendiri.

Seringnya bergonta-ganti pasangan adalah dampak buruk bagi lelaki hidung belang yang memanfaatkan poligami. Hal ini berimplikasi pada semakin besar risiko terkena penyakitpenyakit kelamin seperti HIV/AIDS, dsb. Tentunya kemungkinan terbesar menjadi korban adalah perempuan, sebab rasionya yang lebih banyak dibandingkan laki-laki dalam praktik poligami ini.

Walaupun dalam prespektif gender dipandang demikian, para pelaku poligami sebaiknya tidak melupakan ibadah kepada Allah SWT. Niatkan berpoligami untuk ibadah kepada Allah semata, bukan sebagai ajang pelampiasan nafsu semata. Bagi istri, berpoligami juga bukan karena suami atau harta, melainkan peroleh ridho Allah.

Adab lain yang perlu dijaga adalah dalam berpoligami adalah mampu menjaga kehormatan istri-istrinya. Seorang suami memiliki kewajiban membimbing dan mendidik istrinya untuk hidup di jalan yang lurus sesuai syariat agama. Sebab suami adalah pemimpin keluarganya. Apabila ia membiarkan istrinya bersikap bebas dan bermaksiat, maka suami pun juga ikut berdosa. Sebagaimana firman Allah Allah SWT dalam QS At-Tahrim, ayat: 6 yang artinya:

"Wahai orang-orang yang beriman, jagalah diri-diri kalian dan keluarga kalian dari api neraka yang bahan bakarnya adalah manusia dan batu."

Poligami akan indah dijalani selama satu sama lain saling menjaga kehormatan, menjadikan mahligai rumah tangga sebagai perahu dalam bahtera ketauhidan. Sehingga tiada penyelewengan dan kezaliman yang dilakukan suami, dan istri melayani suami, melakukan tanggung jawab domestik, merawat dan mendidik anak, murni karena mencari ridho Ilahi.

\section{Tasawwuf Falsafi Dan Irfani}

\section{a. Karakteristik Tasawwuf Falsafi}

Meminjam istilah al-Taftâzânî, tasawuf yang dikembangkan Ibn Arabî dikenal sebagai tasawuf falsafî1 ${ }^{120}$. Menurut Abdul Aziz Dahlan, tasawuf falsafî berarti suatu paham tasawuf

\footnotetext{
${ }^{120}$ Muhammad Afif Anshori, Kontestasi Tasawuf Sunni dan Tasawuf Falsafi di Nusantara. Jurnal Tasawuf dan Pemikiran Islam. Volume 4, Nomor 2, Desember 2014. hal. 309
} 


\section{An-Nisa', Volume XI Nomor 1 Januari 2018}

yang ajarannya sudah bersifat lebih falsafî, karena meluas ke masalah metafisika, yakni proses bersatunya manusia dengan Tuhan dan sekaligus membahas manusia dan Tuhan ${ }^{121}$. Contoh tasawuf falsafi ialah melalui konsep ke-fana'-an yang tertinggi yakni apabila kesadaran tentang fana' itu sendiri juga hilang (fana' al-fana') yang diungkapkan Hamzah Fansuri dan dikutip al$\operatorname{Attas}^{122}$.

Contoh penerapan tasawuf falsafi lainnya adalah seperti yang dilakukan Shaykh Siti Jenar. Mengenai siapa sesungguhnya Shaykh Siti Jenar itu sampai saat ini masih dianggap misteri dan tokoh fiktif belaka, namun sebagian lainnya menyatakan memang riil. Hal ini terjadi lantaran tidak tersedianya bukti-bukti akurat tentang eksistensinya.

Ketika mengkaji Siti Jenar, hanya ada beberapa rujukan, di antaranya Suluk Shaykh Siti Jenar yang ditulis oleh Raden Sasrawidjaja ${ }^{123}$ dan Suluk Walisango serta beberapa tulisan babad. Siti Jenar yang semula beragama Budha, berguru kepada Sunan Ampel selama tujuh tahun. Selain itu ia juga belajar tafsir, fiqh, termasuk ilmu hakikat dan ma'rifah, $\mathrm{dsb}^{124}$, dari sumber lainnya lagi, ia adalah murid Sunan Giri yang bernama Hasan Ali. ${ }^{125}$

Ajaran pokok Siti Jenar sering disebut dengan Manunggaling Kawula Gusti atau bersatunya manusia dengan Tuhan yang semakna dengan wahhdat al-wujûd-nya Ibn'Arabi. ${ }^{126}$ Pokok ajarannya tersebut dijabarkan dan diklasifikasikan sebagai berikut:

1) Ajaran tentang Tuhan (teologi). Menurut Siti Jenar, persepsinya tentang Tuhan adalah sama dengan pandangan Jabariah dan Qadariyah. Tuhan mempunyai sifat 20, yakni wujûd, qidam, baqâ', mukhâlafatuh li al-hawâdith, qiyâmuh bi nafsih, wahdânîyah, qudrah, irâdah, „ilm, hayâh, samâ', bashar, kalâm; qâdir, murîd, „âlim, hayy, samî', bashîr, mutakallim. Kedua puluh sifat itu berada pada Wujud Mutlak yang disebut Dzat, tak ada ujung pangkalnya, tidak ada asal serta tujuannya.

2) Ajaran tentang Jiwa. Bagi Siti Jenar, yang disebut jiwa itu adalah suara hati nurani yang merupakan ungkapan dari Dzat Tuhan yang harus ditaati dan dituruti perintahnya. Ia membedakan antara apa yang disebut dengan jiwa dan akal. Jiwa, selain merupakan

\footnotetext{
121 Abu al-Wafa'e al-Ghanimi al-Taftazani, Madkhal ila al-Tashawwuf al-Islami, terj. Ahmad Rofi 'Utsmani (Bandung: Pustaka, 1985), h. 187.

${ }^{122}$ Mujamil Qomar. Ragam Pengembangan Pemikiran Tasawuf di Indonesia. Jurnal Episteme. Vol. 9, No. 2, Desember 2014. Hal. 263

${ }^{123}$ Raden Sasrawidjaja, Syekh Siti Jenar (Djogdjajakrta: Keluwarga Bratakesawa, 1958), dilampirkan dalam Abdul Munir Mulkhan, Ajaran dan Kematian Syekh Siti Jenar (Yogyakarta: Kreasi Wacana, 2001).

${ }^{124}$ Wiryapanitra, Babad Tanah Jawa: Kisah Kraton Blambangan dan Pajang (Semarang: Dahara Prize, 1996$), 82$.

${ }^{125}$ Abdul Munir Mulkhan, Syekh Siti Jenar: Pergumulan Islam-Jawa (Yogyakarta: Bentang, 2001), 49-53.

${ }^{126}$ Op.cit. Muhammad Afif Anshori, Kontestasi Tasawuf Sunni dan Tasawuf Falsafi di Nusantara. ..hal. 313
} 
ungkapan kehendak Tuhan, juga merupakan penjelmaan dari Hyang Widi (Tuhan) yang berada dalam jiwa, sehingga badan raga dianggap sebagai wajah Tuhan.

3) Pandangan tentang alam semesta (kosmologi). Siti Jenar memandang alam semesta (makrokosmos/jagad gede) sama dengan manusia (mikrokosmos/jagad cilik), minimal kedua hal itu merupakan barang baru ciptaan Tuhan yang sama-sama akan mengalami kerusakan, tidak kekal dan tidak abadi. Semua aspek keragaan atau ketubuhan adalah barang pinjaman yang suatu saat setelah manusia terlepas dari kematian di dunia ini akan kembali berubah menjadi tanah serta kembali kepada pemilik-Nya. Hubungan jiwa (dari Tuhan) dan raga berakhir sesudah manusia menemui ajal atau kematian duniawi.

Ketubuhan jasmaniah ditinggal karena barang baru (hadith) yang dikenai kerusakan dan semacam barang pinjaman yang harus dikembalikan pada yang punya, yaitu Tuhan sendiri ${ }^{127}$.

4) Pandangan tentang fungsi akal. Dalam pandangan Siti Jenar, fungsi akal banyak dikaitkan dengan intuisi. Pandangannya ini kelak sangat berpengaruh besar terhadap fungsi aturan formal sharî,,ah, khususnya tentang "lima rukun Islam".

5) Ajaran tentang perbuatan manusia (af'âl al -'ibâd). Dalam berbagai pupuh, nampak jelas bahwa pandangan Siti Jenar mengenai perbuatan manusia sebagai kehendak Tuhan seperti pandangan Jabariyah. Tuhan adalah Dzat yang mendasari adanya manusia, hewan, tumbuh-tumbuhan dan segala yang ada, yang adanya tergantung pada adanya Dzat itu.

6) Ajaran tentang Manunggaling Kawula Gusti yang hampir sama maknanya, yakni kebersatuan hamba dengan Tuhan. Konsep ini tidak bisa dipahami secara literal belaka, melainkan harus dikaitkan dengan pengalaman tasawuf sufi lainnya yang sejenis, semisal Abû Yazîd al-Bist\}âmî ataupun Abû Mansûr al-Hallâj. Sebagaimana ucapan Abu Yazid pada shalat shubuh ${ }^{128}$, saat membaca QS. Thaha ayat: 14 yang artinya:

\footnotetext{
${ }^{127}$ Ibid. hal.75

${ }^{128}$ A.J.Arberry, Muslim Saints and Mystics, terj. Anas Mahyuddin (Bandung: Pustaka Salman, 1983), 132.
} 


\section{An-Nisa', Volume XI Nomor 1 Januari 2018}

"Aku adalah Tuhan, tiada Tuhan selain Aku dan karena itu sembahlah Aku".

Jika ayat itu dibaca oleh manusia, maka pada hakekatnya manusia meniada. Suatu saat Siti Jenar datang memenuhi undangan Dewan Walisongo untuk berdiskusi tentang doktrin Sufi, ia menjelaskan doktrin kesatuan makhluk, yaitu dalam pengertian yang Akhir hanya Allah yang ada. Selain itu tidak ada perbedaan ontologis yang nyata yang bisa digambarkan antara Allah, manusia dan segala ciptaan lainnya. Sunan Giri mengatakan bahwa doktrin itu benar, tetapi ia meminta jangan diajarkan karena bisa membuat kosong masjid dan orang mengabaikan ${\text { syari' }{ }^{129}}^{129}$.

Di samping itu, perlu pemahaman aqidah yang kuat dalam memahami konsep ini. Sebaiknya jika ada yang ingin mengritik tasawuf harus menggunakan kacamata atau prespektif tasawuf pula, karena titik pandangnya berbeda ketika meggunakan epistemologi empiris misalnya.

\section{b. Karakteristik Irfani}

Para pemikir keislaman baik dari kalangan muslim maupun dari kalangan Orientalis mereka berbeda pendapat dalam menentukan asal dan sumber epistemologi Irfani ini. Ada yang berpendapat bahwa Pendiri aliran-aliran sufi berasal dari kelompok orang Majusi, seperti Ma`ruf al-Kharki (w. $815 \mathrm{M}$ ) dan Bayazid Busthami (w. $877 \mathrm{M})^{130}$. Irfani berasal dari sumber-sumber Kristen, karena adanya segi-segi kesamaan antara kehidupan para Sufis, dalam soal ajaran, tata cara melatih jiwa (riyadah) dan mengasingkan diri (khalwat), dengan kehidupan Yesus dan ajarannya, juga dengan para rahib dalam soal pakaian dan cara bersembahyang ${ }^{131}$.

Adapun pendapat Horten dan Hartman tentang irfani ditimba dari India, seperti keluasan hati dan pemakaian tasbih adalah praktek-praktek dari India. ${ }^{132}$ Sementara seorang pemikir muslim kontemporer al-Jabiri ${ }^{133}$ lebih condrong pada kelompok Yunani. Menurutnya ${ }^{134}$, Irfani

\footnotetext{
${ }^{129}$ Mark R. Woodward, Islam in Java: Normative and Mysticism in the Sultanate of Yogyakarta, terj. Hairus Salim HS (Yogyakarta: LKiS, 1999), 149.

${ }^{130}$ Yazid Busthami, Farid al-Din al-Attar, Warisan Para Aulia, terj. Anas Muhyidin, (Bandung, Pustaka, 1994). h.48

${ }^{131}$ Nicholson, al-Shufiyah fì al-Islâm, terj. Nurudin Syaribah, (Kairo, tp. 1951), h. 12

${ }_{132}$ Al-Attar, Warisan Para Aulia, terj. Anas Muhyidin, (Bandung, Pustaka, 1994). h. 56

${ }^{133}$ Mohammad Abied Al-Jabiri adalah seorang pemikir Arab kontemporer (asal Maroko) yang memproyeksikan diri dalam proyek pemikiran spesifik selain Hassan Hanafi (asal Mesir) dan Muhammad Arkoun (asal Aljazair). Ketigatiganya dapat dikatakan sebagai "pemikir proyek". Jabiri lahir di Figuig, sebelah selatan Maroko, tanggal 27 Desember 1935. Pendidikannya dari tingkat dasar sampai perguruan tinggi lebih banyak ditempuh di tanah kelahirannya di Maroko. Dia pernah setahun menempuh pendidkan filsafat di Universitas Damaskus, Siria (tahun 1958). Setelah itu dia melanjutkan pendidikan diploma Sekolah Tinggi Filsafat Fakultas Sastra Universitas Muhammad V di Rabat, (1967) dan meraih gelar master dengan tesis tentang "Filsafat Sejarah Ibn Khaldun" (Falsafatut Târîkh 'inda Ibn Khaldûn). Doktor bidang Filsafat, dia raih di Fakultas Sastra Universitas Muhammad V, Rabat (1970), dengan disertasi yang masih membahas seputar pemikiran Ibn Khaldun, khususnya tentang Fanatisme Arab. Desertasinya berbicara tentang "Fanatisme dan Negara: Elemen-Elemen Teoritik Khaldunian dalam Sejarah
} 
diadopsi dari ajaran Hermes, sedang pengambilan dari teks-teks al-Qur`an lebih dikarenakan tendensi politik. Sebagai contoh, istilah maqâmat yang secara lafdzi dan maknawi diambil dari al-Qur`an (QS. Al-Fusilat : 164), identik dengan konsep Hermes tentang mi`raj, yakni kenaikan jiwa manusia setelah berpisah dengan raga untuk menyatu dengan Tuhan. Memang ada kata maqâmat dalam al-Qur`an tetapi dimaksudkan sebagai ungkapan tentang pelaksanaan hak-hak Tuhan dengan segenap usaha dan niat yang benar, bukan dalam arti tingkatan atau tahapan seperti dalam istilah al-Hujwiri (w. $1077 \mathrm{M}$ ).

Mulyadi Kertanegara menjelaskan bahwa ada dua modus dalam memperoleh ilmu pengetahuan yang diakui ilmuwan-ilmuwan muslim: Pertama, "bergerak dari objek-objek yang diketahui menuju objek-objek yang diketahui”. Kedua, "semata-mata merupakan hasil iluminasi langsung dari dunia Ilahi. Modus pengetahuan pertama adalah metode demonstratif atau penalaran logika, sedangkan yang kedua dicapai melalui jalan intuitif. ${ }^{135}$ Menurutnya, metode irfani didasarkan pada pengamatan indriawi atau intelektual (akal), tetapi lebih pada pengamatan intuisi. Adapun ciri khas pengenalan intuitif adalah kelangsungannya, dalam arti pengenalan langsung terhadap objeknya, tanpa melalui perantara (intermediasi). Ini, pada gilirannya, terjadi karena adanya identitas antara yang mengetahui (the knower) dan yang diketahui (the known) atau antara subjek dan objek. ${ }^{136}$

Suhrawardi menerangkan bahwa intuisi mendahului pemahaman teks dan merupakan syarat pencapaian makan. Intuisi merupakan mediasi pencapaian substansi dinamis yang mempolasrisasikannya dari substansi statis maupun al-barazikh (objek-objek pertengahan). Intuisi adalah cahaya, kasyf (penyingkapan), ilmu laduni (yaitu ilmu pengetahuan yang didapatkan secara langsung dari Allah tanpa melalui proses belajar maupun latihan) atau pengalaman spritual yang menghasilkan sebuah ilmu pengetahuan. Sedangkan intuisi dalam pandangan Husserl adalah pencapaian (pencerapan) yang jelas terhadap esensi otonom-independen, atau pandangan kebatinan terhadap objek-objek teporer yang lebih dekat pada pandangan rasional daripada penalaman mistik. ${ }^{137}$

Islam” (Al-‘Ashabiyyah wad Dawlah: Ma’âlim Nadzariyyah Khaldûiyyah fit Târikhil Islâmî). Disertasi tersebut kemudian dibukukan tahun 1971.

${ }^{134}$ Al-Jabiri, Bunyah al-Aql al-Arabi, (Beirut, al-Markaz al-Tsaqafi al-Arabi, 1993), h. 372.

135 Mulyadi Kertanegara, Nalar Religius: Memahami Hakikat Tuhan, Alam Dan Manusia, (Jakarta: PT Gelora Aksara Pratama, 2007), h. 73.

${ }^{136}$ Mulyadi Kertanegara, Integrasi Ilmu Sebuah Rekonstruksi Holistik (Bandung: PT Mizan Pustaka, 2005), h.142.

${ }^{137}$ Hasan hanafi, Islamologi 2: dari Rasionalisme ke Empirisme, penj. Miftah faqih, (Yogyakarta: LkiS, 2004), h. 301. 


\section{An-Nisa', Volume XI Nomor 1 Januari 2018}

Hal di atas dipertegas oleh pendapatnya Murtadha Muthahhari dalam Solihin dan $\operatorname{Anwar}^{138}$, yang menjelaskan bahwasanya, sebagai sebuah ilmu, 'irfan memiliki dua aspek, yakni aspek praktis dan aspek teoritis. Aspek praktisnya adalah bagian yang menjelaskan hubungan dan pertanggungjawaban manusia terhadap dirinya, dunia, dan Tuhan. Sebagai ilmu praktis, bagian ini menyerupai etika. Bagian praktis ini juga di sebut sayr wa suluk (perjalanan rohani). Bagian ini menjelaskan bagaimana seorang penempuhrohani (salik) yang ingin mencapai tujuan puncak kemanusian, yakni tauhid, harus mengawali perjalanan, menempuh tahapan-tahapan (maqam) perjalanannya secara berurutan, dan keadaan jiwa (hal) yang bakal dialaminya sepanjang perjalanannya tersebut.

Jadi, dapat dikatakan bahwa irfani di satu sisi bersifat sebagai suatu ilmi dan juga amali, atau bisa juga dikatakan bahwa irfan ilmi bersifat teoritis sementara irfan amali bersifat praktis. Irfan amali menjelaskan hubungan vertikal antara hamba dan Allah SWT. Di samping itu, membahas tanggung jawab bersama terhadap dirinya sendiri dan dunia yang ada di sekitarnya. Oleh karena itu, irfan amali lebih mirip dengan akhlak dalam tasawuf.

Adapun irfan ilmi berhubungan dengan ontologi yang membicarakan Tuhan, dunia, dan manusia. Aspek ini sangat mirip dengan filsafat teologi. Bidang yang dibahas adalah falsafah ilahiah. Term ini merupakan gabungan antara filsafat dan israqiyah. Dalam istilah Mulla Shandra gabungan kedua aspek tersebut disebut Hikmah Al-M uta'alliyah. Para pesuluk memilki suatu maqam khusus yang di dalamnya mereka sanggup mewujudkan ide-ide otonom menurut bentuk yang mereka kehedaki. Itulah yang disebut sebagai "maqam kun" (mewujudlah!). Setiap kali ia mendaki lebih sempurna, penyaksiannya atas bentukbentuk tersebut akan lebih jernih dan lebih menyenangkan. Ia pun akan terlempar ke dalam cahaya dan terdorong untuk memasuki Sang Cahaya Mahacahaya. ${ }^{139}$

\section{Korelasi Antara Poligami, Tasawwuf Falsafi, Dan Irfani}

Terlepas dari banyaknya stigma buruk tentang poligami, dalam pandangan islam ada hikmah dibalik itu, bukannya tanpa sebab. Jika kita mampu memahami, sebenarnya praktek poligami yang benar dan sesuai syariat memiliki banyak faedahnya, antara lain ${ }^{140}$ :

\footnotetext{
${ }^{138}$ M. Solihin dan Rosihon Anwar, Ilmu Tasawuf, (Bandung: Pustaka Setia, 2008), h h. 146.

139 Syihab Ad-Din Yahya As-Suhrawardi, Hikmah Al-Isyraq: Teosofi Cahaya Dan Metafisika Huduri, terj. Muhammad Al-Fayyadl (Yogyakarta: Islamika, 2003), h. 213.

140 Dalami Islam, Pusat Ilmu Nusantara. 5 syarat poligami dalam islam danu dalilnya. https://dalamislam.com/hukum-islam/pernikahan/syarat-poligami-dalam-islam 9, 2017, Diakses pada tanggal 04 Januari 2019
} 
1) Jumlah wanita di dunia lebih banyak daripada laki-laki. Dengan berpoligami, setidaknya kesempatan wanita untuk menikah akan meningkat

2) Mengangkat derajat wanita. Apabila wanita itu miskin dan tidak bisa menafkahi diirnya sendiri, maka dengan dipoligami ia akan tercukupi kebutuhan hidupnya

3) Meningkatkan jumlah turunan atau penerus islam

4) Apabila wanita pertama mandul, dan suami ingin memiliki anak maka keinginannya bisa terpenuhi dengan berpoligami

5) Mempererat ukhuwah islamiyah. Apabila antar istri dapat berlaku baik, maka akan tercipta hubungan persaudaraan yang indah

6) Mungkin istri pertama sakit-sakitan sehingga kebutuhan biologis suami tak terpenuhi. Maka suami dibolehkan poligami dengan cara baik dan lewat persetujuan istri pertama.

Kita bisa memaknai kedalaman sufistik dalam poligami dari konsep tasawuf falsafi dan irfani. Jalaludin Ar Rumi dalam kumpulan syair Matsnawinya mengungkapkan bahwa:

\section{Wanita adalah cahaya Tuhan}

\section{Dia bukan kekasihmu}

Tetapi dia lah pencipta

\section{Pencipta yang tidak diciptakan untukmu semata}

Secara kodrati, perempuan ialah bayang-bayang (tajalliyat) Tuhan di semesta ini, yang disebut oleh Ibnu Arabi (sufi islam) sebagai miniatur semesta atau mikrokosmos, yang dalam dirinya mencerminkan bagian-bagian dari alam ini. Karenanya sungguh benar adanya bila para sufi islam ahli ma'rifat mengatakan untuk meningkatkan derajat kewalian salah satu caranya adalah menyintai dan menyayangi wanita. Lelaki yang memiliki pandangan irfani, (melihat Tuhan dalam diri wanita). Ia takkan menzalimi perempuan, karena menyakitinya, berarti menyakiti Penciptanya. 


\section{An-Nisa', Volume XI Nomor 1 Januari 2018}

Dari segi tasawuf, kalangan sufi menyebut maskulin, keras, perkasa sebagai 'jalal' (keagungan) atau aspek 'Yang'. Sebaliknya, bentuk keindahan, kecantikan, sifat feminin, atau aspek 'jamal' (keindahan) adalah aspek 'Yin'. Dengan penyatuan kedua prinsip inilah - Yin dan Yang - kehidupan terus di alam ini selalu ada. Pengorganisasian segala sesuatu ke dalam dua kelompok serta melihat segala penciptaan berdasarkan kedua aspek ini dalam kehidupan samasama penting. Karena tanpa intervensi keduanya, tak akan ada kehidupan baru di muka bumi.

Tujuan penciptaan (kosmologi) selalu didasarkan pada keseimbangan dan kesatuan baik dalam alam lahiriah maupun batiniah. Esensi kehidupan manusia baik perempuan atau laki-laki adalah untuk menjadi insan kamil, yaitu manusia yang dapat menyatukan sisi ilahiah jamal (keindahan/kualitas feminin) dan jalal (keagungan/kualitas maskulin) menjadi kamal (sempurna).

Ada dalil relasi gender yang seringkali disalahartikan yakni dalam QS. Al Baqarah, ayat: 188, yang artinya: "Istri-istrimu adalah pakaianmu, dan engkau adalah pakaian mereka,". Jika kita menguak pemikiran agamawan kuno, pakaian diibaratkan sebagai "keakuan yang lain" (alter-ego), yakni pakaian difungsikan sebagai pengganti untuk seseorang, dan dengan pakaian baru seseorang seolah mendapatkan kepribadian baru. Padahal makna pakaian adalah menyembunyikan tubuh, menutupi pandangan terhadap bagian-bagian yang bersifat pribadi, dan melindungi pemakainya, dan secara sufistik pakaian itu berarti pelindung untuk menjaga kesucian.

Menurut interpretasi ini, suami-istri berbicara satu sama lain kepada alter-ego mereka, dan setiap diri melindungi kehormatan pasangannya. Hal ini memperlihatkan betapa baiknya prinsip 'Yin-Yang' berlaku dalam hubungan perkawinan yang berarti, "Hubungan suami-istri adalah setara dalam kebersamaan mereka yang sempurna", termasuk pada rana poligami. Dibalik sosok pasangan - suami - ataupun "madu" bagi istri lain, terdapat "Wajah Tuhan". Segala perbuatan diperuntukkan hanya pada Nya, bukan untuk dunia dan seisinya, karena segala yang ada selain Dia hanyalah kefanaan. Dia lah Kekasih (baca: Tuhan) yang abadi bagi suami maupun istri. MenjadikanNya Tujuan adalah Kebahagiaan Sejati. 


\section{Kesimpulan}

Kunci kelanggengan ikatan pernikahan baik monogami maupun poligami tentunya adalah karena landasan cinta. Meski demikian, jika hakikat cinta ini didasari hanya pada pasangan atau kebahagiaan dunia belaka, maka wajar jika percekcokan terjadi.

Olehnya itu, dari konsep tasawuf falsafi dan teori irfani ini, diharapkan agar tiap pasangan atau landasan pernikahan seyogianya adalah menambatkan cinta suci itu pada Sang Maha Cinta, dalam peleburan diri serta ego hingga fana menujuNya. Bukankah kita akan menuju pada kehidupan abadi, dimana hanya amalan serta kecintaan rosul dan Allah yang akan menjadi penolong? Hal ini memang tak mudah, karena jalan pesuluk harus dengan kesadaran total bahwa Tiada yang Wujud selainNya.

Di samping itu, sifat Jalal dan Jamal Tuhan terbentuk melalui Yin dan Yang yang terjewantahkan pada semesta sebagai makrokosmos dan pada diri manusia secara mikrokosmos. Sehingga dalam berpoligami pun, tiap orang dalam keluarga itu tidak akan berbuat karena berharap pujian yang lain. Tapi semua pilihan dan pengkhidmatan terpatri hanya pada Ilahi Rabbi.

\section{Daftar Pustaka}

Al-Attar, 1994. Warisan Para Aulia, terj. Anas Muhyidin, Bandung, Pustaka.

Al-Jabiri, 1993. Bunyah al-Aql al-Arabi, Beirut, al-Markaz al-Tsaqafi al-Arabi.

Al-Taftazani, Abu al-Wafae al-Ghanimi, 1985. Madkhal ila al-Tashawwuf al-Islami, terj. Ahmad Rofi 'Utsmani Bandung: Pustaka.

Anshori, Muhammad Afif. 2014. Kontestasi Tasawuf Sunni dan Tasawuf Falsafi di Nusantara. Jurnal Tasawuf dan Pemikiran Islam. Volume 4, Nomor 2.

Arberry, A.J., 1983. Muslim Saints and Mystics, terj. Anas Mahyuddin. Bandung: Pustaka Salman.

As-Suhrawardi, Syihab Ad-Din Yahya, 2003. Hikmah Al-Isyraq: Teosofi Cahaya Dan Metafisika Huduri, terj. Muhammad Al-Fayyadl. Yogyakarta: Islamika.

As-Syarbini, Syekh M Khatib, Mughnil Muhtaj, Beirut, Darul Fikr, tanpa keterangan tahun, juz 3. 


\section{An-Nisa', Volume XI Nomor 1 Januari 2018}

Az-Zuhayli, Syekh Wabash, 1985. Al-Fiqhul Islami wa Adillatuh, (Beirut, Darul Fikr, cetakan kedua, juz 7.

Busthami, Yazid, Farid al-Din al-Attar, 1994, Warisan Para Aulia, terj. Anas Muhyidin, Bandung, Pustaka.

Fiqhiyyah, Mausu'atul, 2002. Wazaratul Awqaf was Syu'unul Islamiyyah, (cetakan pertama, Kuwait, M/1423 H), juz 41.

Hanafi, Hasan, 2004. Islamologi 2: dari Rasionalisme ke Empirisme, penj. Miftah faqih, Yogyakarta: LkiS.

Kertanegara, Mulyadi, 2005. Integrasi Ilmu Sebuah Rekonstruksi Holistik. Bandung: PT Mizan Pustaka.

Kertanegara, Mulyadi , 2007. Nalar Religius: Memahami Hakikat Tuhan, Alam Dan Manusia, Jakarta: PT Gelora Aksara Pratama.

Mulkhan, Abdul Munir, 2001. Syekh Siti Jenar: Pergumulan Islam-Jawa. Yogyakarta: Bentang.

Nicholson, 1951. al- Shufiyah fî al-Islâm, terj. Nurudin Syaribah, Kairo.

Sasrawidjaja, Raden. 1958. Syekh Siti Jenar .Djogdjajakrta: Keluwarga Bratakesawa, dilampirkan dalam Abdul Munir Mulkhan, Ajaran dan Kematian Syekh Siti Jenar (Yogyakarta: Kreasi Wacana, 2001).

Solihin, M. dan Anwar, Rosihon, 2008. Ilmu Tasawuf, Bandung: Pustaka Setia.

Qomar, Mujamil. 2014. Ragam Pengembangan Pemikiran Tasawuf di Indonesia. Jurnal Episteme. Vol. 9, No. 2.

Schimmel, Annemarie .2000. Dimensi Mistik Dalam Islam, terj. Supardi Djoko Damono dkk. (Jakarta: Pustaka Firdaus.

Wiryapanitra, 1996. Babad Tanah Jawa: Kisah Kraton Blambangan dan Pajang. Semarang: Dahara Prize.

Woodward, Mark R., 1999. Islam in Java: Normative and Mysticism in the Sultanate of Yogyakarta, terj. Hairus Salim HS. Yogyakarta: LKiS.

Zuhro, Rif'atuz. 2015, Poligami, antara islam, cinta, dan realitas. http://www.nu.or.id/post/read/64601/poligami--antara-islam-cinta-dan-realitas. Diakses pada tanggal 05 Januari 2019

2017. 5 syarat poligami dalam islam danu dalilnya. https://dalamislam.com/hukumislam/pernikahan/syarat-poligami-dalam-islam 9, Diakses pada tanggal 04 Januari 2019 